\title{
Thinking with Stanner in the present
}

\author{
Melinda Hinkson
}

In recent years the work of Australian anthropologist W. E. H. Stanner has enjoyed something of a revival. To mark the centenary of his birth in 2005, Jeremy Beckett and I organised a conference and then edited An Appreciation of Difference, ${ }^{1}$ a volume of scholarly essays exploring various dimensions of Stanner's career and his legacy in the present. Just a few months after that book came out, Black Inc. published The Dreaming and Other Essays ${ }^{2}$ - essentially a reissuing of Stanner's White Man Got No Dreaming, with an introductory essay by Robert Manne celebrating Stanner as the greatest essayist Australia has ever produced. ${ }^{3}$ The attention paid to these books in the mainstream press reveals a deep and abiding interest in Stanner's work, especially the essays he wrote for a wide public, and suggests that his insights are well suited to be taken up in continuing debates about the place of Aboriginal people in Australian society. Marcia Langton writing in the Australian Literary Review, ${ }^{4}$ Christopher Pearson in the pages of The Weekend Australian, ${ }^{5}$ Inga Clendinnen in The Monthly ${ }^{6}$ and Keith Windschuttle in Quadrant ${ }^{7}$ all turned their attention variously to Stanner's work. And in their recent books, Noel Pearson ${ }^{8}$ and Peter Sutton ${ }^{9}$ have drawn on Stanner's writings to help sustain their critical attention to past policymaking and their visions for the future. In this essay, I explore Stanner's legacy as a key thinker, but not in the sense with which we tend to conventionally deploy this notion. Here, I am interested to explore how Stanner's work is being mobilised in current public political debate, to examine what kind of 'thinking with' Stanner is being undertaken in the politics of the present.

\footnotetext{
1 Hinkson, Melinda and Beckett, Jeremy (eds) 2008, An Appreciation of Difference: WEH Stanner and Aboriginal Australia, Aboriginal Studies Press, Canberra.

2 Stanner, WEH 2009, The Dreaming and Other Essays, Black Inc., Melbourne.

3 Robert Manne, 'WEH Stanner: the anthropologist as humanist', in ibid., p. 4.

4 Langton, Marcia 2009, 'Chronicler of a disaster foretold', Australian Literary Review, pp. 17-18.

5 Pearson, Christopher 2009, 'Stanner's Aboriginal essays show their age', The Australian, 21 March.

6 Clendinnen, Inga 2009, 'The good solider', The Monthly, April, pp. 56-61.

7 Windschuttle, Keith 2009, 'Bill Stanner and the end of the Aboriginal High Culture', Quadrant, no. 5 (May), viewed 10 September 2009, <http://www.quadrant.org.au/magazine/issue/2009/5/bill-stanner-andthe-end-of-aboriginal-high-culture $>$

8 Pearson, Noel 2009, Up From the Mission: Selected writings, Black Inc., Melbourne.

9 Sutton, Peter 2009, The Politics of Suffering: Indigenous Australia and the end of the liberal consensus, Melbourne University Press, Carlton.
} 
Running through my essay is a reflection on the issue of 'presentism' - the use of scholarly work of an earlier era to address contemporary concerns. In an important essay on the theme, historian of anthropology George Stocking ${ }^{10}$ describes presentism as a kind of 'Whiggish history' in which the end goal is judgment not understanding. From the perspective of the presentist, according to Stocking, history is taken to be 'the field of dramatic struggle between children of light and children of darkness'.$^{11}$ In this characterisation, Stocking evokes nicely some of the tenor of Australia's history wars and the culture wars that have followed. Indeed, a concern to reveal the presentism at work in recent history making has been a strong theme of post-Mabo critical scholarship in Australia. Bain Attwood's critique of Henry Reynolds' deployment of 'juridical history' - representing the past in such a way that it might be made available to legal and quasi-legal judgments in recognition of Aboriginal rights in landis the most well-articulated case. ${ }^{12}$ While the use of aspects of Stanner's work by contemporary writers needs to be distinguished from the kind of critique Attwood is making of Reynolds and the specificity of these issues as they concern historians, I want to suggest that at a formal level a similar process is in operation, and presentism is a useful concept with which to think about some recent readings of Stanner's works.

Historically, Australians have imagined the cultural difference of remote-living Aboriginal people through two broad sets of representations: one positive, the other negative. While both positive and negative stereotypes coexist, it is by and large the case that one kind of image has dominated in any particular era and broadly influenced the public and policy attention to the Aboriginal problem. Since the mid-1990s, we have been witnessing the re-ascendency of the negative stereotype. Across this transition, two different possible readings of Stanner have been undertaken as his ideas have been appended to conflicting political projects. Before turning to consider these issues of the present, we must, however, lay the foundations for a broader understanding of the development and application of Stanner's thinking.

\section{Beginnings}

William Edward Hanley Stanner was born in Sydney in 1905, the second of three children, to a family of modest means. His father died when William

10 Stocking, George 1968, 'On the limits of "presentism" and "historicism"', Race, Culture and Evolution: Essays in the history of anthropology, The Free Press, New York, pp. 1-12.

11 Ibid., p. 4.

12 See Attwood, Bain 1996, 'The past as future: Aborigines, Australia and the (dis)course of history', Australian Humanities Review, April 1996, viewed 28 May 2010, <http://www.australianhumanitiesreview. org/archive/Issue-April-1996/Attwood.html> See also Curthoys, A., Genovese, A. and Riley, A. 2008, Rights and Redemption: History, law and Indigenous people, UNSW Press, Sydney, especially pp. 32-6, ch. 2. 
was just three and, like others of his generation and class background, young Stanner left school early to help support the family. He found work in a bank before establishing himself in the more interesting world of journalism. He took himself off to night school and after matriculating enrolled in a degree at Sydney University in 1928. After a chance meeting early on with the newly arrived Alfred Reginald Radcliffe-Brown - the dashing foundation chair of anthropology - Stanner changed course from economics to anthropology. ${ }^{13}$

By all accounts, Radcliffe-Brown was an inspirational lecturer and Stanner's lecture notes attest to this. In reading these notes, there is a clear sense of a discipline in the process of being moulded by one of its founding figures; in many of these lectures, Radcliffe-Brown was in critical engagement with the work of Tylor, Durkheim and Malinowski, as well as introducing his students to the research that would go on to be published as his ground-breaking survey study of Aboriginal Australia. ${ }^{14}$ He moved on from Sydney, however, before Stanner embarked on postgraduate fieldwork. So it fell to A. P. Elkin, then Raymond Firth to supervise Stanner's master's study. After two extensive periods of research in northern Australia, Stanner relocated to London in 1935 to undertake his PhD. For financial reasons, he ended up at the London School of Economics working with Malinowski and Firth, rather than Oxford, where Radcliffe-Brown was now chair. Firth employed Stanner as a research assistant and would become a significant figure in his professional life. While completing his $\mathrm{PhD}$, Stanner continued his work as a journalist, notably for TheTimes, in which he also published important feature articles on the plight of Australia's Aborigines. ${ }^{15}$

In 1938, having completed his $\mathrm{PhD}$, Stanner travelled to East Africa, where he spent time before and after the war. ${ }^{16}$ Stanner's time in Africa was formative in a number of respects, particularly for the insights he gained into the fraught arena of development. In Africa, he was able to place something of the situation he had observed in northern Australia in wider perspective. The war and his time in Africa and further afield kept Stanner working outside Australia for more than a decade. Finally, in 1949, he secured his first tenured academic position when he was appointed Reader of Comparative Social Institutions in the Research School

\footnotetext{
13 See Barwick, Diane, Beckett, Jeremy and Reay, Marie 1985, 'WEH Stanner: an Australian anthropologist', in Diane Barwick, Jeremy Beckett and Marie Reay (eds), Metaphors of Interpretation: Essays in honour of WEH Stanner, The Australian National University Press, Canberra, pp. 1-52.

14 See, for example, Stanner, W. E. H. 1930, ‘Notes taken in Radcliffe-Brown's Social Anthropology II Lectures, 1930', MS 3752, Series 2, Item 2, W. E. H. Stanner Collection, AIATSIS Library, Canberra.

15 See, for example, Stanner, W. E. H. 1937, 'Dying races of Australia', The Times (London), 25 November 1937, p. 15.

16 See Melinda Hinkson, 'Stanner and Makerere: on the "insuperable" challenges of practical anthropology in post-war East Africa', in Hinkson and Beckett, An Appreciation of Difference, pp. $44-57$.
} 
of Pacific Studies at The Australian National University. In the next decade and a half, Stanner would re-immerse himself in the anthropology of Aboriginal Australia and write his most important work.

Through the 1960s, he took on increasingly public roles - notably, on the Council for Aboriginal Affairs alongside H. C. 'Nugget' Coombs and Barrie Dexter; he appeared as expert witness in Milirrpum versus Nabalco, the unsuccessful challenge of the Yolngu against the establishment on their lands of a giant bauxite mine, in what we have come to know as the first land rights case; and, in 1968, he became the first anthropologist to be invited to give the Australian Broadcasting Commission's Boyer Lectures. His series After the Dreaming has been referred to as among the most important Australian lectures ever given.

In our introduction to An Appreciation of Difference, Jeremy Beckett and $\mathrm{I}^{17}$ suggest that Stanner's career was a tussle between two kinds of commitments. He had a driving ambition to contribute to public life that was evident early on, cut across by a deep intellectual interest in the questions of social process with which anthropology is concerned. These two interests were not necessarily incompatible, as illustrated in the working lives of a number of Stanner's contemporaries, but an increasing burden of public responsibility in his later life kept Stanner from writing the books he imagined he might complete. In fact, the corpus of published work Stanner left behind is relatively small; aside from various articles, we have his book about postwar reconstruction in the Pacific, The South Seas in Transition, his series of scholarly essays published as an Oceania monograph, On Aboriginal Religion, his Boyer lectures, After the Dreaming, and his collected essays, White Man Got No Dreaming. Of these, it is the Boyer Lectures and a small number of essays from White Man Got No Dreaming for which Stanner continues to be widely known.

\section{Structural functionalism and the 'rotting frontier'}

It is in the context of Stanner's scholarly training that we find the issues that continued to animate and frustrate his anthropological interests for the rest of his working life. Stanner's teachers were of the generation that established anthropology as a professional discipline. They rejected cultural evolutionism and were concerned with documenting the diversity of ways of being human in the present. Yet paradigm shifts in thinking occur through a series of stages, and scholars of Stanner's generation and training encountered a paradox lodged in

17 Jeremy Beckett and Melinda Hinkson, "“Going more than half way to meet them": on the life and legacy of WEH Stanner', in Hinkson and Beckett, An Appreciation of Difference, pp. 1-23. 
the idea that anthropology was concerned with the present. That idea was cut across by the directive that social change could not be grappled with until culture itself had first been explained. ${ }^{18}$ This idea presumed 'culture' to take some kind of original form against which the complex mess of colonial encounter might then be mapped. This idea - that anthropology recorded 'culture' first, then 'change' - was clearly articulated in Radcliffe-Brown's teachings, as Stanner's lecture notes make clear. Paradoxically, this idea ensured that anthropology would continue to look not to the present, but back through time, to some imagined pre-colonial order, as the space where the most valued forms of social life were to be sought and documented.

We might observe that this culture-centred approach entailed a particular twist on presentism. On the one hand, 'the present' was articulated as the focus of anthropological concern; this was what set ethnographic research apart from ethnology. In reality, however, 'the present' was itself eschewed in favour of a more graspable object: culture or society delineated and composed as a set of identifiable (or imagined) structures and practices. This was scholarship undertaken in the interests of the present in that it established a clear and legitimised field of practice, with its own ethical temper; cultures had to be documented 'before it was too late' (that is, before they were gone - the direction of cultural change was at this time still assumed to be inevitable). What this approach also ensured was a set of scholarly practices that need not account for the conditions of their own making; the colonial encounter was a secondary or even peripheral concern for anthropological description and analysis. It was not that Radcliffe-Brown and his contemporaries sought to make colonialism invisible; it was rather that they had no theoretical capacity to make sense of the processes of which they were themselves a part. They also did not have any real interest in doing so; social-scientific scholarship of this era was concerned with a different set of questions. Nevertheless, anthropologists of Stanner's generation encountered the practical implications (and unintended consequences) of such an approach.

Arriving at Daly River by boat in April 1932 to begin his first stint of ethnographic fieldwork for his master's thesis, Stanner was confronted with a situation vastly different from what he had expected. The linguist Gerhardt Laves had told him the area was home to 'half a dozen unstudied tribes who spoke no English'. On arrival, however, Stanner observed 'English was understood by nearly every native on the river, many of them speaking it with a fluency that makes pidgin

18 Stanner, 'Notes taken in Radcliffe-Brown's Social Anthropology II Lectures, March 24, 1930', MS 3752, Series 2, Item 2, W. E. H. Stanner Collection, AIATSIS Library, Canberra; cf. Radcliffe-Brown, A. R. 1958 [1931], 'The present position of anthropological studies', in M. N. Srinivas (ed.), Method in Social Anthropology: Selected essays, University of Chicago Press, Ill., pp. 42-95, at p. 77. 
a misnomer' and most were working for peanut farmers. ${ }^{19}$ We might imagine that as an anthropologist in training, Stanner found himself immediately in a situation in which theory meets reality and finds itself wanting. And indeed his master's thesis might be read as a direct response to this conundrum. It also established the interests with which Stanner would continue to be occupied for the rest of his working life. So let us conjure up this environment that Stanner unwittingly wandered into and would come to describe as the 'rotting frontier'.

The history of cultural contact on the Daly River was replete with bloody, violent and complicated encounters between settlers and Aboriginal people of the region. Stanner wrote in his diary just a week after his arrival that he was 'already convinced' it would prove to be 'a most valuable key area for intensive enquiry into cultural contacts and dislocation'. The first explorers had named the Daly River in 1865; Chinese agriculturalists established the first farm in the area soon after. In the early 1880s, copper was discovered in significant quantities by five fossickers who set up a mine and permanent camp. In September 1884, four of them were speared to death. In the reprisals that followed, the Aboriginal Protector, Dr R. J. Morice, reported that as many as 150 men, women and children were shot and killed. ${ }^{20}$ In the next decade, Jesuit missionaries failed in separate attempts to establish a viable mission at three different locations, before finally quitting the Northern Territory altogether. A series of agricultural experiments followed. In 1908, a large government farm was established in an effort to attract significant numbers of settlers to the area. Free blocks of land and generous financial payments were made to 34 settlers. Dairying, pigs, fruit trees and other crops were all tried unsuccessfully. In the years that followed, peanuts were successfully harvested, but this was far from fertile land and the 1930s worldwide depression served only to deepen the dire circumstances of the Daly farmers. By the time Stanner arrived, just 12 of the original settlers remained. All were growing peanuts; all relied on local Aboriginal labour; most were deeply in debt. ${ }^{21}$ Hostilities between Aborigines and settlers intensified as the worsening financial situation meant that paying workers their allocations was becoming increasingly difficult. While the settlers were dependent on Aboriginal labour, these dependencies became mutual in light of Aboriginal people's strong desire for tobacco, sugar and tea. There were incidents of theft, quarrels over Aboriginal women and many antagonisms to do with maltreatment and underpayment of workers. In one noted episode, a settler was so determined to prevent his precious stores being raided that he planted dynamite under the boards of his hut so that any person entering

19 See Hinkson, Melinda 2005, 'The intercultural challenge of Stanner's first fieldwork', Oceania, vol. 75, pp. 195-208, at p. 199.

20 Stanner, W. E. H. 1934, Culture contact on the Daly River. Draft for thesis, University of Sydney, MS 3752, Series 1, Item 9, W. E. H. Stanner Collection, AIATSIS Library, Canberra, p. 27.

21 This discussion is taken from Hinkson, 'The intercultural challenge of Stanner's first fieldwork', p. 199. 
the house during his absence would trigger the charge. ${ }^{22}$ This was a rough place - a 'rotting frontier' along which Stanner observed layers of cross-cultural misunderstanding leading to many conflicts and where social order appeared to be unravelling.

The circumstances of this first fieldwork had a profound influence on the trajectory of Stanner's anthropology. ${ }^{23}$ It was here that Stanner established a concern with the problem of change or cultural transformation. As he reflected later in life:

I have argued that Aboriginal life is not to be thought of (as some anthropologists seem implicitly to think of it) as naturally or inherently stable but, on the contrary, as prone to instability. I take the disposition to change, as it were, for granted, as something that does not really have to be accounted for. ${ }^{24}$

In this regard Stanner was a thinker ahead of his times. He was also, however, constrained by the conceptual tools available to him and more particularly by his continuing commitment to Radcliffe-Brown's approach. What Stanner identified as his own failure to account for the problem of Daly River social organisation we might rephrase in terms of the impossibility of disentangling Aboriginal social organisation from the colonial context in which he found it. To put it in Radcliffe-Brownian terms, Stanner came up against the problem of sketching culture before tackling change. The two phenomena simply could not be approached separately. Stanner went on to wrestle with this conundrum variously across this work, but it is in two of his essays that have been taken up in the public domain that we find perhaps the most enduring reflections on the matter.

\section{Reading Stanner in the present}

What is it that allows writings of an earlier era to acquire a special resonance in the present? In relation to Stanner's corpus, it might be suggested that the public response to the 1992 Mabo case and the history wars that followed resonated closely with the central ideas put forward in his 1968 Boyer Lectures. In those lectures, Stanner laid down the case for grasping our history in terms of a 'great Australian silence'. Through the public debates and legislative response triggered by Mabo over land-tenure uncertainty, Australia revisited the issues Stanner had identified as lodged at the heart of the nation. His analysis of

22 Stanner, Culture contact, p. 55.

23 Hinkson, 'The intercultural challenge of Stanner's first fieldwork', pp. 195-208.

24 Stanner, W. E. H. n.d., 'The dreamers of Wali Wali', MS 3752, Series 1, Item 162a, Unpublished manuscript, p. 1. 
Australian race relations and of our 'history of indifference' was invoked by a new generation of writers and political activists to stimulate thinking about the moral dimensions of the case and its wider implications for national identity. ${ }^{25}$ Stanner's Boyer Lectures are replete with material that might support this kind of political project. More recently, public debate in relation to Aboriginal affairs has gained a new focus. The urgent object of debate is now not so much history as culture. And it is with this shift in public orientation that new readings of Stanner's work - and in particular two of his essays - have been taken up in a differently oriented presentist project.

'Continuity and change' and 'Durmugam: a Nangiomeri' were written just a year apart, in 1958 and 1959, respectively. These two essays, as in the best of Stanner's writings, take much of their force from the way they reach simultaneously in two directions: into the heart of the Aboriginal life world and into the depths of the Australian psyche. Both essays are concerned with stark realities of cultural transformation and with our intellectual and administrative inability to come to terms with these. Let us turn first to 'Durmugam', which has received the most constant attention in recent public intellectual debate (by Manne, Clendinnen, Windschuttle and Sutton), and which Manne recently described as the finest essay by an Australian' he had 'ever read'. ${ }^{26}$

Stanner wrote this essay for a book edited by American anthropologist Joseph Casagrande on relationships between anthropologists and their informants. It is an anthropological exercise in life writing in the fullest sense: an individual life examined as a prism through which we might also glimpse the broader society around him, as well as the experience of the anthropologist (at least at the level of his own telling). And there is a sense in which this essay, more than any other, cemented Stanner's reputation as a humanist anthropologist.

The essay opens in dramatic fashion with a fight scene: Stanner describes Aboriginal men, 'garishly painted up' in 'savage, vital splendour', the air filled with flying spears. ${ }^{27}$ After a period of watching the action, the anthropologist is able to discern a pattern in the chaos, as well as to identify a striking figure of a man who is 'peerless' in his 'display of skill and courage' ${ }^{28}$ At the end of the fight, as if stepping off a film set, this man walks over to Stanner and asks him if he 'liked the fight'. Stanner asks who he is and recognises Durmugam as the

25 See, for example, Pearson, Noel 1994, 'Mabo: towards respecting equality and difference', Voices from the Land: 1993 Boyer Lectures, Australian Broadcasting Corporation, Sydney, pp. 89-101; Clendinnen, Inga 1999, True Stories, Boyer Lectures, Australian Broadcasting Corporation, Sydney, especially Lecture Six: 'What next?', viewed 29 May 2010, <http://www.abc.net.au/rn/boyers/stories/s74430.htm>

26 Manne, 'WEH Stanner', p. 4.

27 Stanner, W. E. H. 1979 [1959], 'Durmugam: a Nangiomeri', White Man Got No Dreaming: Essays 1938-

1973, The Australian National University Press, Canberra, p. 67.

28 Ibid., p. 69. 
man known to Europeans as 'Smiler', the most 'murderous black of the region'. In the weeks that follow, it becomes clear that Stanner has found in Durmugam his ideal informant.

In recounting Durmugam's life story, Stanner reveals the harshness of life in remote northern Australia in the early decades of the twentieth century and the kinds of transformations that occurred in the lives of Aboriginal people as they became organised, through mutual dependency, around the peanut farms. 'Many of the preconditions of the traditional culture were gone', observes Stanner: 'a sufficient population, a self-sustaining economy, a discipline by elders, a confident dependency on nature - and, with the preconditions, went much of the culture, including its secret male rites.' ${ }^{29}$ But - and the 'but' is significanthe also recognised the 'vital will' of these people to 'make something of the ruined life around them'. ${ }^{30}$ Durmugam's life emerges as a kind of metaphor for the larger tale of colonial encounter. A life shaped by migration, parental death, close and formative relationships with particular European settlers and, importantly, initiation into what Stanner terms the Aboriginal High Culture. In his estimation, this last experience provides the constitutional anchorage for his subject's sense of self.

At the heart of this essay lies an implicit question: how are we to put together the portrait Stanner paints of this man of good character, who embodies all the qualities an Aboriginal person would put forward as making an honourable man (notably, as Inga Clendinnen has observed, these map very neatly onto our modern figure of the English gentleman), ${ }^{31}$ with the known fact of his having killed four people? It is a question that Stanner can pose usefully for his own purposes, as it enables him to peel back some of the layers of mystique surrounding Aboriginal custom, to reveal some of its complexity and points at which it remained starkly at odds with European law, and moreover, to get at something mainstream Australia seemed unable to grasp: 'what it is to be a blackfellow in the here-and-now of Australian life.' ${ }^{32}$ It is this kind of conception of identity in the process of transformation - conveyed passionately and evocatively in terms that defy the orthodox interests of discipline-based writing - that makes this such a unique and powerful essay.

Stanner places the centre of his moral focus with Durmugam in the last years of his life when, after World War II, he returns to northern Australia and finds his old friend struggling unsuccessfully to hold the parameters of his world

29 Ibid., p. 83.

Stanner [1958], 'Continuity and change among the Aborigines', in ibid., pp. 41-66, at p. 42.

30 Stanner, 'Durmugam', p. 74.

31 Clendinnen, Inga 2005, 'The power to frustrate good intentions', Common Knowledge, vol. 11, no. 3, p. 423.

32 Stanner, 'Durmugam', p. 93. 
together. Durmugam is surrounded by young people with little respect for the principles that frame his sense of the order of the world-nor do they respect the old man himself. His favourite wife has run off with a younger man-worse, she has run off with the son of his first wife, which is a 'great humiliation to a man still alive'; ${ }^{33}$ his eyesight and body are failing him. The system of law to which Durmugam subscribes seems to have lost its moorings, or at least it is unable to help him regain his dignity or repay his sense of justice in this situation. Similarly, Stanner shows us that Durmugam's appeals to the European system of law to provide him with aid fall on deaf ears. Here, a tale emerges of a man caught between two worlds, or rather caught between two imagined orders, neither of which seems to hold traction in the world of the here and now.

Stanner mobilises Durmugam's story as a prism through which to illustrate the senselessness of assimilation. The crucial insight he takes from Durmugam is that 'the only thing he ever liked about Europeanism was its goods' ${ }^{34} \mathrm{He}$ was a unified person who could bridge two worlds, but ultimately found the European way of life 'saltless... and, at the end, bitter too'; 'it never attracted him emotionally, it did not interest him intellectually, and it aroused only his material desires' ${ }^{35}$ And it is this analysis that lies behind Stanner's confident assessment that 'Aborigines like Durmugam can never be "assimilated"'. Towards the end of the essay, Stanner reflects on the issues of 'treachery, hatred, bloodshed' with which Durmugam's story has been concerned and poses the question of whether these things are a product of culture or its decay. He concludes that it is not possible to say. ${ }^{36}$ Significantly, this is the project that Peter Sutton has taken up in his recent book The Politics of Suffering, as I discuss later in this essay.

'Durmugam' is written not so much as an exercise in exploring what is to be done, but rather conjuring up through an individual biography a sense of the lived experience of cultural contact. There is no attempt to resolve the problem posed by the 'flash' young men who were 'no longer listening to anyone or caring for anything', ${ }^{37}$ but rather to show that they posed a problem that neither existing system seemed able to deal with. The essay is as much a celebration of all that Stanner himself admired in Aboriginal society as it is his eulogy for a deeply admired friend. Both Inga Clendinnen and Jeremy Beckett have observed that this essay memorialises an Aboriginal society in a state of demise; in Beckett's words, 'here we are to understand the man and the social order going down together before a misguided policy'.$^{38}$

38 Jeremy Beckett, 'Frontier encounter: Stanner's Durmugam', in Hinkson and Beckett, An Appreciation of Difference, p. 98. 


\section{The uses of Stanner}

Given its themes and the literary flair with which the Durmugam essay is written, it is not surprising it has received so much attention in recent public debate. Keith Windschuttle, ${ }^{39}$ writing in Quadrant in May 2009, observes at the outset that Stanner is 'one of the most impressive essayists this country has ever produced'. In a rare moment of agreement with Robert Manne, Windschuttle declares 'Durmugam' to be Stanner's 'masterpiece', but suggests further that it can be read 'as an argument against the intellectual rationale behind the Coombsian package ${ }^{40}$ that Stanner himself, wearing his hat as government adviser, had long supported'. In other words, Windschuttle reads Stanner the scholar somewhat provocatively to undermine the political vision of Stanner the policy adviser who worked alongside Coombs and Dexter on the Council for Aboriginal Affairs, and with whom the policy program of self-determination is closely identified. This move can be made only via a quite selective reading of 'Durmugam'. Windschuttle starts by ignoring the complex picture Stanner paints of the rotting frontier, overlooking his descriptions of 'mutual dependency' to read that Aboriginal people were in the 1930s by and large living 'customary lives as hunter-gatherers', yet nevertheless 'beleaguering' the white settlers for their provisions. He deploys Stanner's observation of Aboriginal people's voluntary movement off their own lands as they were drawn to the 'powerful magnet' of white society as a counterpoint to Henry Reynolds' model of invasion and resistance - and here Windschuttle reveals the prime motivation behind his attention to Stanner: it allows him to mobilise the work of a scholar who Reynolds credits with triggering his interest in Aboriginal history to directly contradict Reynolds' thesis.

'Instead of patriotically defending their territory and ancient way of life,' Windschuttle writes, 'the Aborigines have accommodated their behaviour and society to the white arrivals. Indeed, many had been positively seduced by the ability of the colonists not only to provide a permanent supply of food, but also the irresistible stimulants tea and tobacco.' ${ }^{41}$ Windschuttle's simplification of Stanner's narrative of cultural contact allows him to make giant leaps: conflict was rare, 'coming in' the norm. If Windschuttle reads the "“coming in" of their own accord' narrative as that which the writing of Aboriginal history has overlooked, he highlights another theme in Stanner's work as having been enthusiastically grasped in public discourse: Stanner's supposedly 'romantic view of traditional Aboriginal culture and his belief that in pre-contact times the

\footnotetext{
39 Windschuttle, 'Bill Stanner and the end of the Aboriginal High Culture'.

40 The 'Coombsian package' Windschuttle refers to was anti-assimilationist and broadly supportive of Aboriginal people having choice in the matter of their own futures. See Rowse, Tim 2000, Obliged to be Difficult: Nugget Coombs' legacy in Indigenous affairs, Cambridge University Press, UK.

41 Windschuttle, 'Bill Stanner and the end of the Aboriginal High Culture', p. 2.
} 
Aborigines had a sophisticated High Culture worthy of intellectual respect' ${ }^{42}$ Yet, Windschuttle continues, Stanner's work, and 'Durmugam' in particular, can be read in quite a different way. Honing in on Durmugam's status as a murderer who escaped retribution, Windschuttle posits Aboriginal society in terms of a Hobbesian state of nature and repudiates the idea that it contained a system of law that should be recognised as equivalent to that of European law. ${ }^{43}$

Windschuttle moves on to track Durmugam's demise in parallel with the demise of the High Culture. He declares that young people 'came to see their future lay more in assimilation than in the religion and values of traditional society' - an observation that again could be made only by passing over Stanner's pointed refutation - that is, that the ideal of assimilation could not deal with the lived experience of Daly River. ${ }^{44}$ He then jumps abruptly from Daly River to Port Keats/ Wadeye (two very different places with very different histories) and recounts a list of violent incidents reported in that township in the past decade and quotes at length from an ex-Wadeye schoolteacher's memoir (published in an earlier issue of Quadrant), an apocalyptic account of children running riot; we might simplify borrowing Stanner's words, an account of young people 'listening to no-one and caring for nothing'. Windschuttle puts Wadeye forward as 'one of the most typical' of remote communities (one wonders on what grounds he is able to generalise with such confidence) - a community where lives are being wasted while we southerners worry about the demise of the High Culture. And he ends with a juxtaposition: while the demise of the High Culture, he confidently states, could not have been 'halted by anyone' - as it was 'caused by an inevitable and irresistible force: the intrusion into traditional society of the modern world' - the tragedy of Wadeye was a different matter altogether. This was a 'product of optional policies, chosen and endorsed by white intellectuals and tertiary-educated Aboriginal activists either on the basis of political ideology, or in the case of those like Stanner, by a mistaken view of how to adapt to the outside world'. In conclusion, Windschuttle suggests, 'had Stanner lived to see the outcome of the policies he recommended, there is little doubt he would have looked on in horror and demanded a revaluation' ${ }^{45}$

I suggested earlier that in Australian political debate the history wars have in some sense given way to the culture wars. Windschuttle, however, articulates their points of connection and continuity. His essay also demonstrates how two conflicting political projects can make productive use of Stanner's work by performing selective readings and deploying these in the public domain. The reason I pay Windschuttle's reading of Stanner so much attention is that he is 
by no means a lone voice. His approach in the Quadrant essay also exemplifies a certain way of reading scholarly work in contemporary public debate-as just one kind of source among many that might be given equal weight. Here Windschuttle typifies a mode of public discourse that emerged in the era of the Howard government and has continued since, in which anecdote - the view of the person on the street-becomes elevated over other kinds of evidence to legitimise certain kinds of policymaking. ${ }^{46}$ In the past decade, Stanner's work has been mobilised in support of diverse political projects-projects that at times are in direct contest with each other. This is the case if we read Ralph Folds' book Crossed Purposes, for example, with its narrative of Pintupi defiance of the State's attempts to coerce them into certain models of citizenship, against Peter Sutton's argument in The Politics of Suffering that a considerable part of the explanation for the current crises of remote Aboriginal Australia is to be found in Aboriginal custom, and indeed Noel Pearson's enlisting of Stanner in support of his argument for programmatic community development. ${ }^{47}$

Perhaps paradoxically it is the rich texture and humanist quality of Stanner's work that leaves it open to be read so divergently. Quite simply, he provides us with a picture of Aboriginal social life that is unusually multifaceted, that documents and weighs up contradictory forces, while resisting the urge to generalise or reach some final point of judgment in accounting for that life. Those wishing to read Stanner in line with particular presentist projects have ample material to draw on, whether the skew of interpretation in regard to Aboriginal circumstances is positive or negative. To extract from Stanner in this way is of course to misread him. While 'Durmugam' might be particularly suited for mobilisation in current debates, I want to turn now to an essay Stanner wrote a year earlier, to give us a different handle on these issues, and indeed on Stanner's legacy.

\section{Stanner's rejoinder}

'Continuity and change among the Aborigines' was written as the presidential address to the Australian and New Zealand Association for the Advancement of Science in Adelaide in 1958. Stanner starts off by observing that the focus of that conference is on the 'Aborigines and the future' and he makes some ironic comments about having just returned from fieldwork in the north where he was caught up studying 'their past'. This reference is, however, more than a throwaway line; the central argument Stanner makes in this address is that

\footnotetext{
46 Hinkson, Melinda 2007, 'In the name of the child', in Jon Altman and Melinda Hinkson (eds), Coercive Reconciliation: Stabilise, normalise, exit Aboriginal Australia, Arena Publications, Carlton North, Vic., pp. 6-7. 47 Pearson, Noel 2009, 'Radical hope: education and equality in Australia', Quarterly Essay, no. 35, Black Inc., Melbourne.
} 
while Aboriginal tradition is widely observed to be collapsing or already collapsed, there remain fundamental continuities from the past to the present that are 'likely to have force into the future' - in short, Stanner suggests, 'until Aborigines cease to be themselves' ${ }^{48}$ On his most recent visit to Daly River, which was also the time of his last meeting with Durmugam, Stanner had observed a deep generational divide between the interests of men Durmugam's age and their children and grandchildren. Where he wrote pessimistically about the implications of this divide in his 'Durmugam' essay, in 'Continuity and change' he insists that while such differences exist, young people's 'activities and interests are in many ways still recognisably Aboriginal' ${ }^{49}$

'The Aborigines I know,' he tells his audience, 'seem to me to be still fundamentally in a struggle with us. The struggle is for a different set of things, differently arranged from those which most European interests want them to receive. ${ }^{50}$ The struggle is in part against the

official view that henceforth the Aborigines must be treated as 'individuals' and not as 'groups'. I am afraid this shows that authority does not know what it is doing. No policy or law can transform the Aboriginal from what he is in this region - a social person, tied to others by a dozen ties which are his life - into an abstract 'individual'. ${ }^{11}$

He goes on to observe the marked ontological distinctions between Aboriginal and European ways of being:

There is a sense in which The Dreaming and The Market are mutually exclusive. What is The Market? In its most general sense it is a variable locus in space and time at which values - the values of anythingare redetermined as human needs make themselves felt from time to time. The Dreaming is a set of doctrines about values - the values of everything - which were determined once-for-all in the past. The things of The Market-money, prices, exchange values, saving, the maintenance and building of capital — which so sharply characterise our civilisation, are precisely those which the Aborigines are least able to grasp and handle. ${ }^{52}$

So, here is an echo of his characterisation of Durmugam, but for the entire society: Aboriginal people were interested in the material vestiges of European

48 Stanner, Continuity and change, p. 41.

49 Ibid., p. 42.

50 Ibid., p. 42.

51 Ibid., p. 43.

52 Ibid., p. 58. 
culture, but thoroughly disinterested in the logic and principles that grounded them. They were, he suggested, 'as far as ever from grasping its rationale, its form, or its values. They still wanted to go their own way. ${ }^{53}$

Stanner refutes what he calls the 'pathetic fallacy' - the idea that Aboriginal people were simply passive victims of history. He describes their active pursuit of European things and their voluntary movement off their customary lands. As we have seen, it is this aspect of Stanner's analysis that Windschuttle is particularly keen to emphasise - but note: Stanner refuses to interpret this in terms of a rejection of an Aboriginal way of life; 'here we have', he suggests, 'a people exploring a potential of their structure, a people taking advantage of its flexibility' ${ }^{54}$ Here Stanner gives short shrift to two dominant ideas: the idea that Aboriginal people were simply run over by the superior force of European society, and the idea that the decline of traditional culture resulted simply in a chaotic mess. 'The one thing that seems to continue,' he observed,

is the effort of the restless, if baffled, Aborigines to work out terms of life they know how to handle. This is why they develop rather than alter, substitute rather than forgo, and give in only to try and outwit. Plainly visible through the process is the fact that [Aboriginal life] has a system, as every process must. It is as plain as daylight that this system is still fundamentally Aboriginal in type. ${ }^{55}$

In Stanner's sights in this address is not only the misunderstanding of government and public, but anthropology as well. Most significantly, he suggests that grappling with these processes of change is beyond the conventional frame of interest and methods of structural functionalism. 'There is,' Stanner suggests, 'a wholesome fear in modern anthropology of overloading abstractions with reality.' And this can be read as his observation on the limits of structuralfunctionalist method and its concern with social structure. Again, Stanner's undergraduate lecture notes make clear where Radcliffe-Brown stood on such matters. He went to some lengths to spell out to his students what the scientific approach to anthropology did not include: paramount here was 'the observation of society on the basis of everyday life'. Descriptions of the every day, RadcliffeBrown told his students, had no place in scientific inquiry. ${ }^{56}$ Three decades after taking down these directions in the lecture theatre, Stanner was able to observe:

We thus sometimes beg the question whether we have consulted the right reality in the first place. Behind the forms we abstract are men with ideas... One of our problems is just the implicitness or wordlessness of 
some of the conceptions still powerfully affecting the Aborigines. Often one is not too sure even of the questions to ask, or of the right ways to ask them. ${ }^{57}$

While we might read pessimism into this reflection, it is clear that Stanner is asking us to see something else - not simply the demise of culture, but rather that culture itself was emerging to take forms that our own epistemological frameworks were not yet able to grasp. And accordingly, he ends his paper with the suggestion that '[w]e now need new minds and new points of view, even if only about old ideas' $;{ }^{58}$ it was time for a generational change at both theoretical and policy levels of engagement.

We cannot know where Stanner's thinking might have led him were he alive today. What we can do is look at the way in which his ideas are being taken up and the political work they are being mobilised to do in the present. Significantly, his observations on the limitations of modern anthropology's concern with abstractions evoke something that both Sutton and Windschuttle are attempting to grasp in their similarly framed critiques of self-determination policy. While it may appear provocative pairing Sutton with Windschuttle - especially given the former's deeply insightful work on Stanner published elsewhere ${ }^{59}$ and the lack of scope to rehearse the argument of The Politics of Suffering in any detail here $^{60}$ - there is a clear sense in which Sutton's project in The Politics of Suffering and that of Windschuttle are attuned. Sutton draws on Stanner's descriptions of fighting in 'Durmugam' to support his thesis that pre-colonial Aboriginal society was violent. He identifies core tenets of Aboriginal culture, as described by Stanner, as maladapted to modernity. Like Windschuttle, Sutton's book calls for a rejection of the 'romantic view' of Aboriginal culture and for what he sees as an overcommitment to abstract principles of Aboriginal 'rights' that has got in the way of us caring for Aboriginal persons.

There is a sense in which Sutton can be read as working in the tradition of Stanner, in his espoused desire to expose aspects of Aboriginal experience to public scrutiny that heretofore had been hidden from view, but Stanner had his focus simultaneously trained on a confluence of contributing factors that Sutton overlooks. Windschuttle obfuscates in order to suit his political argument, ignoring scholarly work that might lead him to draw a differently inflected

57 Stanner, Continuity and change, p. 63.

58 Ibid., p. 66.

59 See Peter Sutton, 'Stanner's veil: transcendence and the limits of scientific inquiry' and 'Stanner and Aboriginal land use: ecology, economic change, and enclosing the commons', in Hinkson and Beckett, An Appreciation of Difference, pp. 115-25, 169-84.

60 See Hinkson, Melinda 2009, 'The trouble with suffering: review of Peter Sutton's The Politics of Suffering', Arena Magazine, no. 101, pp. 54-7. 
picture of present-day circumstances at Wadeye, for example. ${ }^{61}$ Lattas and Morris argue that Sutton has done the same in his construction of a narrative of Cape York history that selectively focuses on certain events, painting the influence of the mission in a positive light while overlooking the impact of mining and the state-directed removal of children. ${ }^{62}$ Both Sutton and Windschuttle arrive at the same conclusion: seeing Aboriginal society as in a dire state requiring radical redevelopment - the remaking of Aboriginal personhood in line with mainstream individualist values. ${ }^{63}$ Their selective reading of Stanner's work is undertaken to help justify a contemporary politics of 'practical care'.

The examples of presentist uses of Stanner's work we have briefly considered here turn on particular conceptual moves. First, they eschew the more complex understanding of culture Stanner was reaching for. Second, they collapse important distinctions that need to be made between self-determination as Coombsian or Stannerian policy vision, as Aboriginal aspiration, and the way a set of government programs was in fact implemented on the ground. In relation to the first - the problem of culture - we have a model caught between two imagined forms: High Culture and its collapse. Here I have shown that while he documented these two types himself, Stanner was strongly of the view that it was limitations in our own capacity to grasp the complex messiness of Aboriginal ways of life in the present that led us to formulate things thus. If culture is understood as either whole or broken (as it is by Windschuttle and Sutton) then there is only one sensible political solution: assimilation, or mainstream integration. As Stanner himself put it pointedly, however, 'we have persuaded ourselves we have only two options - the methods of the past and assimilation' ${ }^{64}$ Moreover, Tim Rowse has drawn attention to what he calls Stanner's 'characteristic dubiety': ${ }^{65}$ Stanner was circumspect on the question of what the future would hold for Aboriginal people. Contrary to what some of his critics suggest, Stanner's writings offer 'no manifesto for "self-determination"'. ${ }^{66}$

The conundrum of self-determination can of course be apprehended only from the perspective of our time, not Stanner's. And here we should note that a growing body of anthropological work has revealed the points of articulation, contradictions and gaping crevices between policy ideas, their implementation

61 See, for example, Alberto Furlan, 'Indigenous songs as "operational structures of transactional life": a study of song cycles at Wadeye', in Hinkson and Beckett, An Appreciation of Difference, pp. 151-65.

62 Lattas, Andrew and Morris, Barry 2010, 'The politics of suffering and the politics of anthropology', in Jon Altman and Melinda Hinkson (eds), Culture Crisis: Anthropology and politics in Aboriginal Australia, UNSW Press, Sydney, pp. 61-87.

63 Altman, Jon and Hinkson, Melinda 2010, ‘Very risky business: the quest to normalize remote Aboriginal Australia', in G. Marston, J. Moss and J. Quiggin (eds), Risk, Responsibility and the Welfare State, Melbourne University Press, Carlton, pp. 185-211.

64 Stanner, Continuity and change, p. 55; emphasis added.

65 Rowse, Tim, 'After The Dreaming: the Boyer lecturer as social critic', in Hinkson and Beckett, $A n$ Appreciation of Difference, p. 252.

66 Ibid., p. 259. 
on the ground and the kinds of imperatives and aspirations Aboriginal people have in mind when they deploy the term 'self-determination'. Quite simply, to see self-determination as a concept that might simultaneously bear the weight of these different processes is - to borrow a phrase used by Stanner in another context - to ignore 'the vexing heterogeneity of...ethnographic facts' ${ }^{67}$

This brings us back to the question of Stanner's own anthropological inheritance and his latter-day critical awareness of the limitations of that body of thought. Writing to his student and friend T. N. Madan in 1962, Stanner revealed his awareness of the limits of the thinking of his teachers in characteristically evocative terms:

I respect both [Radcliffe-Brown's] and [Malinowski's] memories: they taught me much, but neither ever really satisfied me. We have to use the natural science approach - but we have to avoid [Radcliffe-Brown's] effort of making human, man-made facts seem non-human; and we have to grasp more of the creative and aspirational side of man than [Malinowski] did. How odd the scheme of 'primary and derived needs' now seem! What 'derived needs' prompt me to write poetry in my private moments? ${ }^{68}$

Stanner both did and did not transcend the constraints of his time. So many years after he penned these essays they still mark gaps in our capacity to grasp the present and to imagine possible futures. Their richness ensures we will continue to mine these essays for interpretative insights and put them to work in support of diverse political programs for years to come. Indeed, recent public debate and policymaking indicate we have some considerable distance to travel before the full complexity of Stanner's ethnographic observations might be allowed to filter through to public thinking.

67 Stanner, W. E. H. 1953, The South Seas in Transition: A study of post-war rehabilitation and reconstruction in three British dependencies, Australasian Publishing Company, p. 422.

68 Cited in Barwick, Beckett and Reay, 'WEH Stanner', p. 27. 